\section{Research Square \\ Preprints are preliminary reports that have not undergone peer review. \\ They should not be considered conclusive, used to inform clinical practice, or referenced by the media as validated information.}

\title{
The effect of an educational intervention on nurses' knowledge of managing endotracheal tube cuff pressure in intensive care units: A quasi-experimental study
}

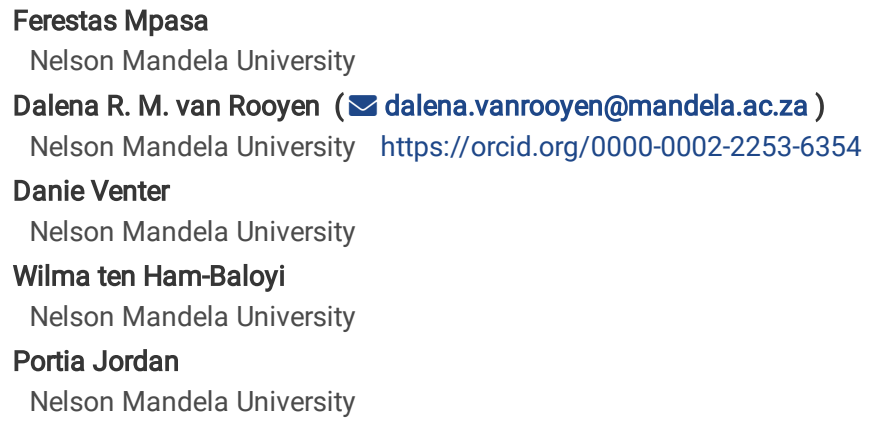




\section{Abstract}

Background Previous studies conducted on nurses' knowledge regarding endotracheal tube cuff pressure revealed that there were differences in intensive care nurses' knowledge, leading to varying practices. This study aimed to evaluate the effect of an educational intervention based on existing evidence-based guidelines, on the knowledge of nurses regarding managing endotracheal tube cuff pressures in Malawian intensive care units.Methods The study followed a quasi-experimental approach, with a pre- and post-test design using an educational intervention. Intensive care unit nurses were randomly assigned to two intervention groups. Both groups received a half-day educational session, a printed version of the evidence-based guidelines, a printed and laminated summary of the guidelines and a related algorithm. Additionally, Group 2 received four monitoring visits. Pre-and post-test questionnaires were conducted between February and August 2016. Descriptive and inferential data analysis (a chi-square test and t-test) were utilised.Results Knowledge on the nursing care practices for the management of endotracheal tube cuff pressure was improved for both groups following the educational intervention, although only the results comparing the Intervention 2 group participants' indicate that the level of knowledge were significant $(t(d . f .=48)=2.08, p=0.043, d=0.59)$. Conclusions The implementation of a formal training programme and mentorship programme for nurses working in the intensive care unit in Malawi would be of great benefit to equip nurses with adequate knowledge and skills for managing endotracheal tube cuff pressure. Follow-up studies would also assist in understanding how the implementation of guidelines could be done most effectively to achieve better knowledge outcomes among nurses concerning nursing care practices in this context.

\section{Background}

Mechanical ventilation, which is used to treat life-threatening conditions, has become a way of managing critically ill patients ${ }^{1}$. However, regardless of the advancement modalities of mechanical ventilation, the technology may contribute to physiological and psychological complications if not well managed ${ }^{2}$. Complications, such as aspiration pneumonia, tracheal stenosis, adhesions and tracheal malacia, have been reported ${ }^{2-4}$. The complications can be minimised or prevented, if evidence-based guidelines are used in the management of endotracheal tube (ETT) cuff pressure ${ }^{5}$. The management of ETT cuff pressure in mechanically ventilated adult patients requires nurses working in intensive care units (ICUs) to have the responsibility of using evidence-based guidelines that direct them in keeping ETT cuff pressure within the normal ranges of $20-30 \mathrm{cmH}_{2} 0$ or $18-22 \mathrm{mmHg} \mathrm{g}^{6,7}$. Furthermore, evidence-based guidelines enable the standardisation of care regarding the management of ETT cuff pressure so that neither over- nor under-inflation of the cuff occurs ${ }^{6}$.

Evidence-based guidelines are defined as systematically developed statements based on best evidence of recommended practice in a specific clinical or health work environment ${ }^{8}$. In the ICU, the use of evidence-based guidelines is essential, as they ensure the successful management of ETT cuff pressure and significantly reduce the risk of tracheal injuries in mechanically ventilated patients ${ }^{9}$.

To enhance the uptake and implementation of evidence-based guidelines, multiple strategies can be used. These strategies include passive methods, such as printed material and formal lectures, as well as active methods, such as educational sessions, audits, feedback, educational outreach visits, academic detailing and videoconferencing ${ }^{10}$. Implementation strategies target improving the organisational structure; changing or improving patient care processes; and changing patients' or professional healthcare workers' behaviour ${ }^{8}$.

Implementation strategies in the form of educational programs should be implemented to enhance the nurses' knowledge. This is especially important, as previous studies conducted on nurses' knowledge regarding ETT cuff pressure revealed that there were differences in ICU nurses' knowledge, leading to varying practices ${ }^{11-17}$. A study by Mohammed et al. ${ }^{12}$ showed that an educational programme including discussion groups and formal lectures accompanied by suitable teaching aids, such as handouts, posters, coloured pictures and a programme booklet, improved the knowledge of the nurses regarding ETT cuff pressure.

The first author observed that $50 \%$ of adult patients admitted to ICUs in Malawi were mechanically ventilated. Furthermore, three quarters of the ICUs did not have evidence-based guidelines for the management of ETT cuff pressure in mechanically ventilated adult patients. However, no study regarding the management of ETT cuff pressure in ICUs had been conducted in Malawi. In addition, the first author observed that the non-availability of guidelines for the management of ETT cuff pressure in some ICUs often led to inadequate knowledge of ETT cuff pressure practices. These observations highlighted the need for implementing, and evaluating the effect of, evidence-based guidelines on the management of ETT cuff pressure in mechanically ventilated adult patients by ICU nurses in Malawi.

\section{Methods}

\section{Design}

The study employed a quasi-experimental design, with pre- and post-tests, using an educational intervention with two groups of nurse participants.

\section{Setting}

The study was conducted in the six functional ICUs (4 public and 2 private) in Malawi. The average bed capacity was four, except one public ICU in which there were six beds. In both set-ups there were more nurses trained on-the-job than those who had undergone formal intensive care nursing specialisation training.

\section{Participants}


An independent observer divided the four public ICUs and the two private ICUs into two intervention groups so that each group contained one private and two public ICUs, using simple randomisation. First, the names of one private and two public hospitals were randomly picked from bowls containing the names of private and public hospitals separately. The names of the first set of hospitals were then placed in an envelope. The second set of hospitals was put in another envelope. These envelopes were then placed in a basket, and the first envelope chosen by the same independent observer would be the intervention group receiving the full educational intervention.

For both the pre- and post-test questionnaires, the targeted population was the nurses working in the selected ICUs for the duration of the study. The total number of nurses working in the six ICUs during the study was 61. The small population made it unnecessary to calculate a minimum sample size, as the research plan was to include as many of the population as possible. Due to the small number of nurses available in Malawi, convenience sampling was used to include as many as possible of the nurses available during the study. In total, 48 nurses were included in the pre-test questionnaire and of 52 participants were included in the post-test questionnaire.

See Figure 1 for the sampling framework.

\section{The intervention}

An educational intervention was developed, based on existing evidence-based guidelines for the management of ETT cuff pressure in mechanically ventilated adult patients ${ }^{13}$. The educational intervention consisted of a half-day educational session using a PowerPoint presentation; a printed version of the evidencebased guidelines; a summary of these guidelines; a related algorithm; and four monitoring visits. These guidelines were validated and reviewed for their relevance to the Malawian ICU context by six professional experts who were purposively selected, based on their ICU experience in Malawi, using the Appraisal of Guidelines for Research \& Evaluation (AGREE) II tool ${ }^{18}$. The experts comprised of one lecturer teaching critical care nursing at a university level, one anaesthetist in a central hospital, one ICU nursing unit manager (ICU trained) and three nurses working in three different ICUs.

Thereafter, a PowerPoint presentation was developed that was used for a half-day orientation to the concepts of the evidence-based guidelines. The PowerPoint presentation included a definition of mechanical ventilation; indications for mechanical ventilation; complications of mechanical ventilation; the management of ETT cuff pressure; the complications of ETT cuff pressure; and the prevention of ETT cuff pressure complications. A summary of the evidence-based guidelines and an algorithm for the management of ETT cuff pressure in mechanically ventilated adult patients were printed and laminated. The monitoring visits involved one-on-one sessions between the first author and the ICU nurses regarding the importance of adhering to the evidence-based guidelines; how the nurses were coping with the implementation of the guidelines; and problems faced in implementation of these. Any uncertainties linked to the guidelines were clarified during these sessions. The educational intervention was reviewed regarding its relevance by the second author, who is an experienced ICU nurse.

The Intervention 1 group (who served as the control group) received only a half-day educational session using a PowerPoint presentation; printed and laminated evidence-based guidelines; a summary of these; a related algorithm; and no monitoring visits (only passive implementation strategies). The Intervention 2 group received the full educational intervention using both active (monitoring visits) and passive implementation strategies.

\section{Data collection instrument}

For the pre- and post-test questionnaires, structured questionnaires were used, adapted with permission from Jordan ${ }^{13}$. Both pre-and post-test questionnaires had two sections. Section A (5 items) involved the demographic data of the nurses working in the ICUs (including gender, age, specialisation in ICU, type of hospital and number of years working in the ICU). Section B captured knowledge related to the nursing care practice for the management of ETT cuff pressure and methods used (6 items), as well as complications of under- and over-inflation of the ETT cuff ( 2 items). The items included in the questionnaires were as follows: (1) frequency of monitoring ETT cuff pressure; (2) methods used to monitor ETT cuff pressure; (3) position of the patient during monitoring of ETT cuff pressure; (4) recommended ETT cuff pressure to be maintained; (5) management of audible leaks; (6) amount of air used to inflate an ETT cuff; (7) complications of under-inflation of the ETT cuff pressure; and (8) complications of over-inflation. An overall knowledge score was calculated for each respondent, based on the percentage of correct responses to the aforementioned items.

\section{Data collection}

Data from the pre-test questionnaire were collected in February-March 2016 using a hand-delivered self-administered questionnaire. A detailed explanation was given to each participant regarding the objectives of the study prior to their signing a consent form agreeing to participate. The participants were assured that the study would not pose risks to themselves or to the patients. Participants were requested not to discuss the questions with their colleagues in order for the answers to truly reflected their knowledge. Questionnaires were collected immediately after completion and secured in an opaque envelope to ensure confidentiality of information. Due to busy schedules and the nurses' shifts in the ICUs, the first author had to visit each ICU several times to complete data collection during the nurses' day shifts. Data from the staff on night shifts was collected just after handover to the day shift at the end of the night shift, or just after handover from the day shift at the beginning of the night shift.

After the pre-test questionnaire was completed by both groups $\left(\mathrm{n}_{1.1}\right.$ and $\left.\mathrm{n}_{2.1}\right)$, the educational intervention was implemented. Both groups were given the halfday educational session using a PowerPoint presentation to prevent performance bias, as both groups would be at the same level of knowledge pertaining to the guideline at the beginning of the implementation of the educational intervention ${ }^{19}$. In addition, both groups received a printed version of the evidencebased guidelines, and a summary of the evidence-based guidelines and the algorithm were printed in bright colours, laminated and posted in high traffic, easyto-see areas, such as at the foot or head of the patient's bed, or on ICU doors (passive implementation strategies). Additionally, for the Intervention 2 group, four monitoring visits using one-on-one sessions with the ICU nurses (active implementation strategy) were conducted during the 3 months of implementation 
(April-June 2016). Data for the post-test questionnaire were collected between July and August 2016 for both groups $\left(\mathrm{n}_{1.2}\right.$ and $\left.\mathrm{n}_{2.2}\right)$ using the same data collection procedure as the pre-test questionnaire.

\section{Data analysis}

Data were analysed using descriptive and inferential statistics. The first author was assisted by the third author, a senior statistician consultant, using visual basic applications in Excel. Means, frequencies, and standard deviations were used for the descriptive analysis, while inferential statistics (such as the chisquare and t-test) was used to analyse the knowledge questions where the Chi test was based on sample frequencies (two or more per sample) and the t-test was based on sample mean values (one value per sample). This facilitated an examination of the level of significance of the nurses' knowledge improvement; the t-distribution and degree of freedom; and the determination of the probability of difference between the two intervention groups.

\section{Validity, reliability and rigour}

The pre- and post-test questionnaires were adapted with permission from Jordan ${ }^{13}$. A small pilot test, which included a cognitive test, was conducted on one participant in order to establish the robustness of the questions in the questionnaires. A Cronbach's alpha calculation was conducted for the eight items used

in the questionnaire that were not multiple response items but were coded $0=$ incorrect and $1=$ correct based on participants' answers. An acceptable Cronbach alpha of 0.60 for these items was achieved.

\section{Results}

Sixty-one questionnaires were delivered and completed by 48 participants (for the pre-test questionnaire) and 52 participants (for the post-test questionnaire), amounting to response rates of $79 \%$ and $85 \%$ respectively. The pre-test questionnaire yielded a Cronbach alpha for knowledge scores of 0.50 , whilst the posttest questionnaire resulted in one of 0.47 . The acceptable reliability interval of 0.50 , which indicated 0.47 , was considered sufficiently close to the required score, although the lower value of the acceptable reliability interval.

\section{Demographic characteristics of participants}

Most of the nurses who completed both the pre- and post-test questionnaire in both intervention groups were female. Most participants were between 25 to 39 years old. Not even a quarter of the nurses were specialised in intensive care nursing. Most nurses were from public hospitals and almost half had worked in the ICU for only a period of 1 to 4 years. Table 1 outlines the demographics of the respondents in both the pre-and post-test questionnaires.

Table 1: Demographic characteristics of the participants (pre-and post-test questionnaires) 


\begin{tabular}{|c|c|c|c|c|c|}
\hline \multirow[t]{2}{*}{ GENDER } & \multicolumn{2}{|c|}{ Intervention 1 group $\left(n_{1}\right)$} & \multicolumn{3}{|c|}{ Intervention 2 group $\left(n_{2}\right)$} \\
\hline & $\begin{array}{c}\text { Pre } \\
\mathrm{n}_{1.1}(\%)\end{array}$ & $\begin{array}{c}\text { Post } \\
\mathrm{n}_{1.2}(\%)\end{array}$ & $\begin{array}{c}\text { Pre } \\
\mathrm{n}_{2.1}(\%)\end{array}$ & \multicolumn{2}{|c|}{$\begin{array}{c}\text { Post } \\
\mathrm{n}_{2.2}(\%)\end{array}$} \\
\hline Male & $3(12)$ & $8(32)$ & $5(22)$ & \multicolumn{2}{|c|}{$4(15)$} \\
\hline Female & $22(88)$ & $17(68)$ & $18(78)$ & \multicolumn{2}{|c|}{$23(85)$} \\
\hline \multirow[t]{2}{*}{ AGE IN YEARS } & \multicolumn{2}{|c|}{ Intervention 1 group $\left(\mathrm{n}_{1}\right)$} & \multicolumn{2}{|c|}{ Intervention 2 group $\left(\mathrm{n}_{2}\right)$} & \multirow{2}{*}{$\begin{array}{l}\text { Total } \\
\text { n (\%) }\end{array}$} \\
\hline & $\begin{array}{c}\text { Pre } \\
\mathrm{n}_{1.1}(\%)\end{array}$ & $\begin{array}{c}\text { Post } \\
\mathrm{n}_{1.2}(\%)\end{array}$ & $\begin{array}{c}\text { Pre } \\
\mathrm{n}_{2.1}(\%)\end{array}$ & $\begin{array}{c}\text { Post } \\
\mathrm{n}_{2.2}(\%)\end{array}$ & \\
\hline$<25$ years & $4(16)$ & $0(0)$ & $1(4)$ & $4(16)$ & $9(9)$ \\
\hline 25-29 years & $8(32)$ & $8(32)$ & $5(22)$ & $8(32)$ & $29(30)$ \\
\hline $30-39$ years & $9(36)$ & $13(52)$ & $7(30)$ & $6(24)$ & $35(36)$ \\
\hline 40-49 years & $2(8)$ & $3(12)$ & $5(22)$ & $5(20)$ & $15(15)$ \\
\hline $50-59$ years & $2(8)$ & $1(4)$ & $4(17)$ & $2(8)$ & $9(9)$ \\
\hline $60+$ years & $0(0)$ & $0(0)$ & $1(4)$ & $0(0)$ & $1(1)$ \\
\hline \multirow{2}{*}{$\begin{array}{c}\text { SPECIALIZED IN } \\
\text { ICU }\end{array}$} & \multicolumn{2}{|c|}{ Intervention 1 group $\left(n_{1}\right)$} & \multicolumn{2}{|c|}{ Intervention 2 group $\left(\mathrm{n}_{2}\right)$} & \multirow{2}{*}{$\begin{array}{l}\text { Total } \\
\text { n (\%) }\end{array}$} \\
\hline & $\begin{array}{c}\text { Pre } \\
\mathrm{n}_{1.1}(\%)\end{array}$ & $\begin{array}{c}\text { Post } \\
\mathrm{n}_{1.2}(\%)\end{array}$ & $\begin{array}{c}\text { Pre } \\
\mathrm{n}_{2.1}(\%)\end{array}$ & $\begin{array}{c}\text { Post } \\
\mathrm{n}_{2.2}(\%)\end{array}$ & \\
\hline Yes & $8(32)$ & $3(12)$ & $6(26)$ & $4(15)$ & $21(21)$ \\
\hline No & $17(68)$ & 22 (88) & $17(74)$ & $23(85)$ & $79(79)$ \\
\hline \multirow[t]{2}{*}{ TYPE OF HOSPITAL } & \multicolumn{2}{|c|}{ Intervention 1 group $\left(\mathrm{n}_{1}\right)$} & \multicolumn{3}{|c|}{ Intervention 2 group $\left(\mathrm{n}_{2}\right)$} \\
\hline & $\begin{array}{c}\text { Pre } \\
\mathrm{n}_{1.1}(\%)\end{array}$ & $\begin{array}{c}\text { Post } \\
\mathrm{n}_{1.2}(\%)\end{array}$ & $\begin{array}{c}\text { Pre } \\
\mathrm{n}_{2.1}(\%)\end{array}$ & \multicolumn{2}{|c|}{$\begin{array}{c}\text { Post } \\
\mathrm{n}_{2.2}(\%)\end{array}$} \\
\hline Government 1 & & & $8(35)$ & \multicolumn{2}{|c|}{$13(48)$} \\
\hline Government 2 & $11(44)$ & $10(40)$ & & & \\
\hline Government 3 & & & $6(26)$ & \multicolumn{2}{|c|}{$6(22)$} \\
\hline Government 4 & $7(28)$ & $6(24)$ & & & \\
\hline Private 1 & & & $9(39)$ & \multicolumn{2}{|c|}{$8(30)$} \\
\hline Private 2 & $7(28)$ & $9(36)$ & & & \\
\hline \multirow[t]{2}{*}{ NO OF YEARS WORKING IN ICU } & \multicolumn{2}{|c|}{ Intervention 1 group $\left(\mathrm{n}_{1}\right)$} & \multicolumn{2}{|c|}{ Intervention2 group $\left(\mathrm{n}_{2}\right)$} & \multirow{2}{*}{$\begin{array}{l}\text { Total } \\
\text { n (\%) }\end{array}$} \\
\hline & $\begin{array}{c}\text { Pre } \\
\mathrm{n}_{1.1}(\%)\end{array}$ & $\begin{array}{c}\text { Post } \\
\mathrm{n}_{1.2}(\%)\end{array}$ & $\begin{array}{c}\text { Pre } \\
\mathrm{n}_{2.1}(\%)\end{array}$ & $\begin{array}{c}\text { Post } \\
\mathrm{n}_{2.2}(\%)\end{array}$ & \\
\hline$<1$ year & $9(36)$ & $5(20)$ & $7(30)$ & $14(52)$ & (35) $35 \%$ \\
\hline $1-4$ years & $11(44)$ & 17 (68) & 9 (39) & $6(22)$ & (43) $43 \%$ \\
\hline $5-9$ years & $3(12)$ & $2(8)$ & $5(22)$ & $3(11)$ & (13) $13 \%$ \\
\hline 10-14 years & $1(4)$ & $1(4)$ & $0(0)$ & $2(7)$ & (4) $4 \%$ \\
\hline$>14$ years & $1(4)$ & $0(0)$ & $2(9)$ & $2(7)$ & (5) $5 \%$ \\
\hline
\end{tabular}

\section{Knowledge of the management of ETT cuff pressure}

Questionnaire responses in respect of the practices related to the management of ETT cuff pressure were statistically treated as knowledge questions and are outlined in Table 2. The results of the post-test questionnaire on the respondents' knowledge of nursing care practices for the management of ETT cuff pressure were superior to those of the pre-test questionnaire. There was an increase in the number of correct answers from the Intervention 2 group for all eight of the relevant questionnaire items except for "B5 Management of audible leaks" (where there was a decline from 96\% to 68\%). The improvement for the 
Intervention 1 group ranged between $6 \%$ (35\% to $42 \%$ ) for "B7 Complications of under-inflation of the ETT cuff pressure" and 68\% (8\% to $76 \%$ ) for "B1

Frequency of monitoring ETT cuff pressure". The improvement for the Intervention 2 group ranged between 10\% (36\% to $46 \%$ ) for "B7 Complications of underinflation of the ETT cuff pressure" and $40 \%$ (30\% to $70 \%)$ for "B1 Frequency of monitoring ETT cuff pressure".

Table 2: Responses to questionnaire items relating to knowledge of nursing care practices for the management of ETT cuff pressure (correct responses are indicated using an asterisk) 


\begin{tabular}{|c|c|c|c|c|}
\hline \multirow[t]{2}{*}{ B1 Frequency of monitoring ETT cuff pressure } & \multicolumn{2}{|c|}{ Intervention 1 group $\left(\mathrm{n}_{1}\right)$} & \multicolumn{2}{|c|}{ Intervention 2 group $\left(\mathrm{n}_{2}\right)$} \\
\hline & $\begin{array}{c}\text { Pre } \\
\mathrm{n}_{1.1}(\%)\end{array}$ & $\begin{array}{c}\text { Post } \\
\mathrm{n}_{1.2}(\%)\end{array}$ & $\begin{array}{c}\text { Pre } \\
\mathrm{n}_{2.1}(\%)\end{array}$ & $\begin{array}{c}\text { Post } \\
\mathrm{n}_{2.2}(\%)\end{array}$ \\
\hline 2 hourly & 7 (28) & $0(0)$ & $5(22)$ & $4(15)$ \\
\hline 4 hourly & $2(8)$ & $1(4)$ & $0(0)$ & $0(0)$ \\
\hline 6 hourly & $4(16)$ & $1(4)$ & $0(0)$ & $1(4)$ \\
\hline 12 hourly* & $2(8)$ & $19(76)$ & $7(30)$ & $19(70)$ \\
\hline Whenever a leak occurs & $8(32)$ & $2(8)$ & $8(35)$ & $2(7)$ \\
\hline Never & $2(8)$ & $2(8)$ & $3(13)$ & $1(4)$ \\
\hline \multirow[t]{2}{*}{ B2 Methods used to monitor ETT cuff pressure } & \multicolumn{2}{|c|}{ Intervention 1 group $\left(\mathrm{n}_{1}\right)$} & \multicolumn{2}{|c|}{ Intervention 2 group $\left(\mathrm{n}_{2}\right)$} \\
\hline & $\begin{array}{c}\text { Pre } \\
\mathrm{n}_{1.1}(\%)\end{array}$ & $\begin{array}{c}\text { Post } \\
\mathrm{n}_{1.2}(\%)\end{array}$ & $\begin{array}{c}\text { Pre } \\
\mathrm{n}_{2.1}(\%)\end{array}$ & $\begin{array}{c}\text { Post } \\
\mathrm{n}_{2.2}(\%)\end{array}$ \\
\hline Listening for air leaks & $8(32)$ & $2(8)$ & $7(30)$ & $4(15)$ \\
\hline Use of minimal occlusive volume technique (MOV) & $0(0)$ & $2(8)$ & $0(0)$ & $6(22)$ \\
\hline Use of minimal leak technique (MLT) & $2(8)$ & $0(0)$ & $0(0)$ & $2(7)$ \\
\hline Use of an aneroid manometer* & $0(0)$ & $6(24)$ & $1(4)$ & $8(30)$ \\
\hline Palpating the cuff with fingers to estimate the pressure in the cuff & $15(60)$ & $15(60)$ & $15(65)$ & $7(26)$ \\
\hline \multirow[t]{2}{*}{ B3 Position of the patient during the monitoring of ETT cuff pressure } & \multicolumn{2}{|c|}{ Intervention 1 group $\left(\mathrm{n}_{1}\right)$} & \multicolumn{2}{|c|}{ Intervention 2 group $\left(\mathrm{n}_{2}\right)$} \\
\hline & $\begin{array}{c}\text { Pre } \\
\mathrm{n}_{1.1}(\%)\end{array}$ & $\begin{array}{c}\text { Post } \\
\mathrm{n}_{1.2}(\%)\end{array}$ & $\begin{array}{c}\text { Pre } \\
\mathrm{n}_{2.1}(\%)\end{array}$ & $\begin{array}{c}\text { Post } \\
\mathrm{n}_{2.2}(\%)\end{array}$ \\
\hline Supine and flat & $5(20)$ & $2(8)$ & $7(32)$ & $0(0)$ \\
\hline Supine to up to 30 degrees & 7 (28) & $8(33)$ & $2(9)$ & $5(19)$ \\
\hline Supine 30 to 45 degrees* & 7 (28) & $10(42)$ & $5(23)$ & $16(62)$ \\
\hline Supine 45-90 degrees & $1(4)$ & $0(0)$ & $0(0)$ & $0(0)$ \\
\hline Lateral position & $1(4)$ & $2(8)$ & $0(0)$ & $0(0)$ \\
\hline No change of position & $4(16)$ & $2(8)$ & $8(36)$ & $5(19)$ \\
\hline \multirow[t]{2}{*}{ B4 Recommended ETT cuff pressure to be maintained } & \multicolumn{2}{|c|}{ Intervention 1 group $\left(\mathrm{n}_{1}\right)$} & \multicolumn{2}{|c|}{ Intervention 2 group $\left(\mathrm{n}_{2}\right)$} \\
\hline & $\begin{array}{c}\text { Pre } \\
\mathrm{n}_{1.1}(\%)\end{array}$ & $\begin{array}{c}\text { Post } \\
\mathrm{n}_{1.2}(\%)\end{array}$ & $\begin{array}{c}\text { Pre } \\
\mathrm{n}_{2.1}(\%)\end{array}$ & $\begin{array}{c}\text { Post } \\
\mathrm{n}_{2.2}(\%)\end{array}$ \\
\hline $18-22 \mathrm{~cm} \mathrm{H} 20$ & $6(24)$ & $15(60)$ & $2(9)$ & $10(38)$ \\
\hline $23-25 \mathrm{~cm} \mathrm{H} 20$ & $3(12)$ & $0(0)$ & $3(13)$ & $2(8)$ \\
\hline $26-30 \mathrm{~cm} \mathrm{H} 20 *$ & $1(4)$ & 7 (28) & $2(9)$ & 9 (35) \\
\hline$>31 \mathrm{~cm} \mathrm{H} 20$ & $0(0)$ & $0(0)$ & $2(9)$ & $0(0)$ \\
\hline Do not know & $15(60)$ & $3(12)$ & $14(61)$ & $5(19)$ \\
\hline \multirow[t]{2}{*}{ B5 Management of audible leaks } & \multicolumn{2}{|c|}{ Intervention 1 group $\left(\mathrm{n}_{1}\right)$} & \multicolumn{2}{|c|}{ Intervention 2 group $\left(\mathrm{n}_{2}\right)$} \\
\hline & $\begin{array}{c}\text { Pre } \\
\mathrm{n}_{1.1}(\%)\end{array}$ & $\begin{array}{c}\text { Post } \\
\mathrm{n}_{1.2}(\%)\end{array}$ & $\begin{array}{c}\text { Pre } \\
\mathrm{n}_{2.1}(\%)\end{array}$ & $\begin{array}{c}\text { Post } \\
\mathrm{n}_{2.2}(\%)\end{array}$ \\
\hline Inflate air despite the air already in the cuff till a leak is not heard any more* & $9(36)$ & $12(48)$ & $6(26)$ & $10(40)$ \\
\hline Notify the physician/anesthetic doctor/surgeon* & $8(32)$ & $9(36)$ & $16(70)$ & $7(28)$ \\
\hline Change position of ETT and patient & $1(4)$ & $0(0)$ & $0(0)$ & $0(0)$ \\
\hline Assess and palpate for cuff pressure & $7(28)$ & $4(16)$ & $1(4)$ & $8(32)$ \\
\hline B6 Amount of air used to inflate an ETT cuff & \multicolumn{2}{|c|}{ Intervention 1 group $\left(\mathrm{n}_{1}\right)$} & \multicolumn{2}{|c|}{ Intervention 2 group $\left(\mathrm{n}_{2}\right)$} \\
\hline
\end{tabular}




\begin{tabular}{|c|c|c|c|c|}
\hline & $\begin{array}{c}\text { Pre } \\
\mathrm{n}_{1.1}(\%)\end{array}$ & $\begin{array}{c}\text { Post } \\
\mathrm{n}_{1.2}(\%)\end{array}$ & $\begin{array}{c}\text { Pre } \\
\mathrm{n}_{2.1}(\%)\end{array}$ & $\begin{array}{c}\text { Post } \\
\mathrm{n}_{2.2}(\%)\end{array}$ \\
\hline $2 \mathrm{mls}$ & $7(28)$ & $5(20)$ & $7(30)$ & $4(15)$ \\
\hline $5 \mathrm{mls}$ & $5(20)$ & $2(8)$ & $3(13)$ & $5(19)$ \\
\hline $10 \mathrm{mls} *$ & $3(12)$ & $6(24)$ & $1(4)$ & $7(27)$ \\
\hline $20 \mathrm{mls}$ & $1(4)$ & $0(0)$ & $0(0)$ & $0(0)$ \\
\hline Inflate till leak disappears despite the air volume already present in the cuff & $3(12)$ & $8(48)$ & $8(35)$ & $10(38)$ \\
\hline Do not know & $6(24)$ & $0(0)$ & $4(17)$ & $0(0)$ \\
\hline \multirow[t]{2}{*}{ B7 Complications of under-inflation of the ETT cuff pressure } & \multicolumn{2}{|c|}{ Intervention 1 group $\left(n_{1}\right)$} & \multicolumn{2}{|c|}{ Intervention 2 group $\left(\mathrm{n}_{2}\right)$} \\
\hline & $\begin{array}{c}\text { Pre } \\
\mathrm{n}_{1.1}(\%)\end{array}$ & $\begin{array}{c}\text { Post } \\
\mathrm{n}_{1.2}(\%)\end{array}$ & $\begin{array}{c}\text { Pre } \\
\mathrm{n}_{2.1}(\%)\end{array}$ & $\begin{array}{c}\text { Post } \\
\mathrm{n}_{2.2}(\%)\end{array}$ \\
\hline Aspiration of gastric contents & $11(44)$ & $8(33)$ & $11(48)$ & $8(32)$ \\
\hline Increase chances of ventilator associated pneumonia & $5(20)$ & $5(21)$ & $4(17)$ & $5(20)$ \\
\hline All the above* & $9(36)$ & $11(46)$ & $8(35)$ & $11(41)$ \\
\hline None of the above & $0(0)$ & $0(0)$ & $0(0)$ & $1(4)$ \\
\hline \multirow[t]{2}{*}{ B8 Complications of over-inflation of the ETT cuff pressure } & \multicolumn{2}{|c|}{ Intervention 1 group $\left(n_{1}\right)$} & \multicolumn{2}{|c|}{ Intervention 2 group $\left(\mathrm{n}_{2}\right)$} \\
\hline & $\begin{array}{c}\text { Pre } \\
\mathrm{n}_{1.1}(\%)\end{array}$ & $\begin{array}{c}\text { Post } \\
\mathrm{n}_{1.2}(\%)\end{array}$ & $\begin{array}{c}\text { Pre } \\
\mathrm{n}_{2.1}(\%)\end{array}$ & $\begin{array}{c}\text { Post } \\
\mathrm{n}_{2.2}(\%)\end{array}$ \\
\hline Tracheal erosion & $3(12)$ & $1(4)$ & $9(39)$ & $0(0)$ \\
\hline Tracheal stenosis & $5(20)$ & $7(28)$ & $7(30)$ & $12(46)$ \\
\hline Tracheal rupture & $6(24)$ & $1(4)$ & $2(9)$ & $3(12)$ \\
\hline Tracheal innominate artery fistula & $1(4)$ & $2(8)$ & $0(0)$ & $0(0)$ \\
\hline All the above* & $9(36)$ & $14(56)$ & $5(22)$ & $10(38)$ \\
\hline None of the above & $1(4)$ & $0(0)$ & $0(0)$ & $1(4)$ \\
\hline
\end{tabular}

Statistics for the knowledge scores calculated for each respondent as the percentage of correct responses to the questionnaire items listed in Table 2 are reported in Tables 3 and 4. As indicated in Table 3, the knowledge of the post-test participants was superior to that of the pre-test participants, with an increase of $12 \%$ (32\% to $44 \%$ ) for the Intervention 1 group and $24 \%$ (13\% to $37 \%$ ) for the Intervention 2 group in the number of respondents with a knowledge score of 40 out of 100 or better. The improvement was, however, not statistically significant for either group. The results for the Intervention 2 group ( $p=.054)$ can be described as reportable $(0.05<\mathrm{p}<0.10)$.

Table 3: Contingency tables - Knowledge scores per group 


\begin{tabular}{|c|c|c|c|c|c|c|c|c|}
\hline \multirow[t]{2}{*}{ Score } & \multicolumn{4}{|c|}{ Intervention 1 group $\left(n_{1}\right)$} & \multicolumn{4}{|c|}{ Intervention 2 group $\left(\mathrm{n}_{2}\right)$} \\
\hline & \multicolumn{2}{|c|}{$\begin{array}{c}\text { Pre } \\
\mathrm{n}_{1.1}(\%)\end{array}$} & \multicolumn{2}{|c|}{$\begin{array}{c}\text { Post } \\
\mathbf{n}_{1.2}(\%)\end{array}$} & \multicolumn{2}{|c|}{$\begin{array}{c}\text { Pre } \\
\mathrm{n}_{2.1}(\%)\end{array}$} & \multicolumn{2}{|c|}{$\begin{array}{c}\text { Post } \\
\mathrm{n}_{2.2}(\%)\end{array}$} \\
\hline $\begin{array}{l}\text { Very low } \\
0-19\end{array}$ & $13(52)$ & $17(68)$ & $10(40)$ & $14(56)$ & $18(78)$ & $20(87)$ & $12(44)$ & $17(63)$ \\
\hline $\begin{array}{l}\text { Low } \\
20-39\end{array}$ & $4(16)$ & & $4(16)$ & & $2(9)$ & & $5(19)$ & \\
\hline $\begin{array}{l}\text { Average } \\
40-60\end{array}$ & $7(28)$ & $7(28)$ & $11(44)$ & $11(44)$ & $3(13)$ & $3(13)$ & $10(37)$ & $10(37)$ \\
\hline $\begin{array}{l}\text { High } \\
61-80\end{array}$ & $1(4)$ & $1(4)$ & $0(0)$ & $0(0)$ & $0(0)$ & $0(0)$ & $0(0)$ & $0(0)$ \\
\hline $\begin{array}{l}\text { Very high } \\
81-100\end{array}$ & $0(0)$ & & $0(0)$ & & $0(0)$ & & $0(0)$ & \\
\hline Total & 25 & 100) & 25 & 100) & 23 & 100) & 27( & 100) \\
\hline Inferentia. & tatistic & (compar & g score & categor & $0-39$ & nd $40-8$ & & \\
\hline Within Int & rvention & 1 group - & Pre and & Post & & $\mathrm{i}^{2}(1)=0$ & $76, p=$. & 82 \\
\hline Within Int & rvention & 2 group - & Pre and & Post & & $i^{2}(1)=3$ & $72, p=$. & \\
\hline Between I & terventi & n 1 and 2 & groups & Pre & & $i^{2}(1)=2$ & $44, p=$ & 19 \\
\hline Between I & terventi & n 1 and & groups & Post & & $i^{2}(1)=0$ & $26, p=$ & \\
\hline
\end{tabular}

As indicated in Table 4, the mean knowledge of the post-test participants was 6.29 and 10.84 higher than that of the pre-test participants in the Intervention 1 and 2 groups, respectively. The improvement was not statistically significant for the Intervention 1 group, but it was significant for the Intervention 2 group.

Table 4: t-Test by pre- and post-test questionnaires for both intervention groups - Knowledge

\begin{tabular}{|l|c|c|c|c|c|c|c|c|}
\hline Group & Test & $\mathbf{n}$ & Mean & S.D. & Difference & $\mathbf{t}$ & $\mathbf{p}$ (d.f.=48) & Cohen's d \\
\hline Intervention 1 & Pre & 25 & 25.14 & 22.69 & 6.29 & 1.00 & .323 & $\mathrm{n} / \mathrm{a}$ \\
\cline { 2 - 6 } & Post & 25 & 31.43 & 21.82 & & & & \\
\hline Intervention 2 & Pre & 23 & 16.15 & 15.11 & 10.84 & 2.08 & .043 & $\begin{array}{c}0.59 \\
\text { Medium }\end{array}$ \\
\cline { 2 - 6 } & Post & 27 & 26.98 & 20.71 & & & & \\
\hline
\end{tabular}

\section{Discussion}

Management of ETT cuff pressure is an essential aspect of nursing care of intubated patients, and the importance of complications related to undesirable cuff pressure cannot be over emphasised ${ }^{20}$. Nurses are at a patient's bedside around the clock, and it is expected of them to be knowledgeable of the complications that can arise when the ETT cuff is under or over ${ }^{3,21}$. Adequate knowledge of practices related to the management of ETT cuff pressure is therefore imperative. The findings of this study show that, although the post-test questionnaire respondents' knowledge of nursing care practices for the management of ETT cuff pressure was superior in both intervention groups, the overall knowledge score of most participants in both groups was low.

Our study results showed that knowledge regarding specific practices was particularly low. Firstly, fewer nurses had knowledge about the correct range of ETT cuff pressure of 22-30 $\mathrm{mmHg}$. Gilliland, Perrie and Scribante 22 stress that tracheal perfusion pressure estimated to be $22-30 \mathrm{mmHg}$, should not be exceeded by the ETT cuff pressure. Exceeding tracheal perfusion pressure impedes tracheal mucosa circulation, which leads to ischemia and the development of lesions. Contradicting with our results are those of a study on ICU nurses regarding the measurement of ETT cuff pressure in Brazil, where in the pre-training period, inappropriate cuff pressure measures (over $30 \mathrm{cmH} 20$ ) during morning, afternoon and evening night shifts were shown $(9.2,11.9$ and $13.7 \mathrm{cmH} 2 \mathrm{O}$, respectively. During the post-training, the inappropriate cuff-pressures were less identified, and there was a significant reduction for the afternoon and eveningnight shifts, respectively $(\mathrm{p}<0.001)^{16}$

Secondly, fewer participants indicated that they would continue cuff inflation, irrespective of the volume of air inserted, or continue cuff inflation, notifying the physician in the pre-test period. Leaks of ETTs in mechanical ventilation cause a loss of volume for positive pressure ventilation and low oxygenation. Sometimes audible leaks are used as a base for monitoring ETT cuff pressure by nurses caring for mechanically ventilated patients ${ }^{23}$. Although the comparison of the groups was not statistically significant, our study revealed an improvement in nursing care practice regarding the management of audible air leaks. Literature recommends that when inflating the ETT cuff $10 \mathrm{mls}$ of air should be used. However, when more than $10 \mathrm{mls}$ is required, notifying the physician regarding the leak is imperative as the cuff might be damaged, thus requiring re intubation of the critically ill patient ${ }^{24}$. Our results are comparable to those of a similar study conducted in South Africa in which only $4 \%$ of 100 participants indicated that they would use $10 \mathrm{ml}$ of air to inflate a leak, which is the best-recommended response, while the rest indicated incorrect responses ${ }^{13}$. 
Thirdly, less than half of the participants in the post-test in both intervention groups indicated that the aspiration of gastric contents and increased chances of ventilator-associated pneumonia are all complications of under-inflation of the ETT cuff, although no statistical significant difference was seen between groups. An ETT cuff pressure below $20 \mathrm{cmH} 2 \mathrm{O}$ is regarded as a contributing risk factor for ventilator-associated pneumonia and ineffective positive pressure ventilation $^{25}$ (Nseir et al., 2011).

Age and experience have been associated with the level of knowledge, as older practitioners have often acquired more experience, which usually translates in better knowledge outcomes ${ }^{26}$. For example, Jansson, Ala-Kokko, Ylipalossari, Syrjiala and Kyngas ${ }^{27}$ found that most nurses who had more than 5 years' experience in ICU scored higher on scientific knowledge of evidence-based guidelines (60.4\%) compared to those with less experience (53.8\%). It could be argued that nurses in the current study scored generally lower in their knowledge related to nursing care practices for the management of ETT cuff pressure since they were relatively young and had less experience than the older, more experienced nurses had.

Mentoring of the younger and/or more inexperienced nurses by 'buddying' them with older, more experienced nurses in the ICU during shifts could assist in increasing knowledge. Mentoring has proven to have positive outcomes on patient care as well as improved job satisfaction among nurses in ICUs, as both junior and senior nurses can experience increased levels of competence, which consequently leads to a reduced attrition rate among nurses ${ }^{28,29}$. A formal mentoring programme is therefore recommended for the ICUs in this study. A mentoring programme was reported to offer a balance in the mentor's mentoring responsibilities with his/her workload, support in terms of acknowledging the mentoring role of these nurses as well as providing access to training and knowledge in this complex environment ${ }^{30,31}$.

ICU training is also considered as being related to an increase in knowledge regarding ICU-related nursing practices. For example, in a study on ICU nurses' knowledge of pain management, glycaemic control and weaning from mechanical ventilation, Perrie, Smchmollgruber, Bruce and Becker ${ }^{32}$ found a significant higher level of knowledge in trained ICU nurses, compared to those that were not formally trained. Further, by virtue of their training, nurses who are specialised in intensive care nursing are considered more knowledgeable regarding nursing care practices, including the management of ETT cuff pressure. In this study, less than a quarter of the participants indicated that they had undergone formal ICU training.

Although it seems to be a common practice for nurses working in ICUs in Malawi and many other lower- and middle-income countries to be trained as they work in the units ${ }^{33}$, our study showed that such in-service training may not be adequate to improve nursing care practices, specifically with regards to the management of ETT cuff pressure. Hence, this could explain the generally low knowledge scores obtained for questions regarding nursing care practices for the management of ETT cuff pressure by the nurses in this study. According to Haniffa et al. ${ }^{34}$, quality training is imperative for good quality care in the ICU. Therefore, it is recommended that nurses in ICUs should be formally trained before positioning them in these units and/or that a structured training programme should be provided to those currently without formal training but working in ICUs. Structured training programmes were found to be associated with a decrease in ICU mortality, and an improvement of other performance indicators, such as discontinuation of vasoactive drugs, earlier discontinuation of mechanical ventilation and earlier ICU discharge ${ }^{34}$.

Furthermore, continuous professional development should be encouraged by frequent in-service training on all practices related to the management of ETT cuff pressure. This is especially important as the overall knowledge score in this study was low, and for some practices, the results showed little improvement in knowledge or even a decline compared to the pre-test questionnaire. It remains unclear whether the improvement in knowledge of some practices was internalised by the nurses who participated in the study and if it would be retained. Continuous professional development, which is critically reflective, constructive, networked and supported with adequate material and technical resources according to nurses' needs and the specific ICU context, should be maintained and encouraged ${ }^{35}$.

In Malawi, the non-availability of guidelines for the management of ETT cuff pressure in ICUs could have contributed to inadequate knowledge in this area. This explains the reason for some non-recommended practices regarding the management of ETT cuff pressure, as these guidelines are tools used to standardise treatment plans and assist health care providers in making evidence-informed clinical decisions ${ }^{21}$.

An improvement in knowledge was observed for certain practices that differed per group. For example, both intervention groups showed the most knowledge improvement regarding the complications of under-inflation of the ETT cuff pressure and the frequency of monitoring ETT cuff pressure. However, knowledge only improved significantly in the Intervention 2 group, where multiple passive and active intervention implementation strategies were employed, including a half-day educational session, printed materials and monitoring visits. Active approaches, including monitoring or site visits, have been proven particularly effective in the implementation of guidelines, but should preferably be part of a multi-faceted approach to effectively improve knowledge among practitioners $^{36}$.

Several limitations were identified in the way this study was conducted. Firstly, it did not include the context of implementation, such as environmental readiness and the stakeholders involved that, according to Harvey and Kitson ${ }^{37}$, should be considered during implementation. The guidelines for the management of ETT cuff pressure in mechanically ventilated adult patients, on which the intervention was based, were reviewed to fit the ICU context in Malawi. However, this research did not consider the possible barriers and facilitators, which should be assessed in order to tailor the implementation strategies to the specific setting and target group ${ }^{38}$. Additionally, the sample size per pre- and post-group for the two groups was too small to conduct inferential statistics for the demographic variables meaningfully and made it impossible to include further variables in the analysis. The demographic differences between the pre- and post-test within both groups were due to the different samples for these groups. However, the participants within each intervention group were the same for the pre- and post-test questionnaires. Randomised sampling could have possibly be used to avoid this, but was not possible due to the already small sample. An attempt was made to include all $\mathrm{N}=61$ in the study, but participation was voluntary, thus a bigger sample could not be achieved. Furthermore, the participants' pre- and post-test data could not be matched as participants responded anonymously. 
Finally, although the management of ETT cuff pressure is mainly conducted by nurses, it forms part of a multi-disciplinary team approach. For continuity of care, the perspectives of stakeholder other than nurses, such as medical specialists or family involved in the care, could have been included in the study. A follow-up study of implementing guidelines using a variety of implementation strategies, testing a larger population and taking into consideration the contextual, demographic and stakeholder issues mentioned, would be helpful in such a complex context.

\section{Conclusions}

The results of this quasi-experimental pre- and post-test study showed varied responses among nurses regarding their knowledge of nursing care practices in the management of ETT cuff pressure. Although most nurses were not formally ICU trained, the implementation of the guidelines led to a general improvement in their knowledge of nursing care practices for the management of ETT cuff pressure. This was specifically the case for the Intervention 2 group where a variety of implementation strategies, including the half-day educational session, printed materials and monitoring visits, significantly improved knowledge. The implementation of a formal training programme and mentorship programme for nurses working in the ICU in Malawi would be of great benefit to empower nurses with adequate knowledge, skills and appropriate attitudes for the management of the ETT cuff pressure. Follow-up studies would also assist in understanding how the implementation of guidelines could be done most effectively to achieve better knowledge outcomes among nurses concerning nursing care practices in the ICU context.

\section{List Of Abbreviations}

ETT - Endotracheal tube

ICU - intensive care unit

\section{Declarations}

\section{Ethics approval and consent to participate}

Ethical clearance was granted from the Faculty of Health Sciences' Postgraduate Studies Committee (ethics number H14-HEA-NUR) and from the National Health Sciences Research Ethics Committee in Malawi (ethics number15/3/139). Approval was obtained from each of the six hospitals involved in the study. Consent was requested from all participants and participation was voluntary. The questionnaires did not include any confidential data.

\section{Consent for publication}

Not applicable as no personal data was used.

\section{Availability of data and materials}

The datasets used and/or analysed during the current study are available from the corresponding author on reasonable request.

\section{Competing interests}

The authors declare that they have no competing interests.

\section{Funding}

This research received no specific grant from any funding agency in the public, commercial, or not-for-profit sectors.

\section{Authors' contributions}

FM conducted the study, DvR and PJ conceptualised and supervised the study, DV analysed the data and WtHB wrote and revised the paper. All authors read and approved the final manuscript.

\section{Acknowledgements}

The authors would like to thank Vicki Igglesden for editing the article and the respondents for participating in the study.

\section{References}

1. Zamzam MA, El Aziza AA, Elhefnawya MY, Shaheen NE. Study of the characteristics and outcomes of patients on mechanical ventilation in the intensive care unit of EL-Mahalla Chest Hospital, Egypt. J Dis Tuber. 2015; 64(3):693-701. http://dx.doi.org/10.1016/j.ejcdt.2015.04.001.

2. Jaillette E, Zerimech F, De Jonckheere J, Makris D, Balduyck M, Durocher A, et al. Efficiency of a pneumatic device in controlling cuff pressure of polyurethane-cuffed tracheal tubes: a randomized controlled study. BMC Anesthesiology [Internet]. 2013 Jan [cited 2019 Sep 12];13(1):50-67. Available from: http://0-search.ebscohost.com.wam.seals.ac.za/login. aspx?direct=true\&db=asn\&AN=93601234\&site=ehost-live\&scope=site

3. Bent S, Toschlog E. Reducing the risk for micro aspiration and post intubation pulmonary complications in the surgical and critical care setting: Innovations in endotracheal tube cuff design. Anaesthesiology News, Special Report, 2012, August https://www.anesthesiologynews.com/MonographsWhitepapers/Article/08-12/Reducing-the-Risk-for-Microaspiration-and-Postintubation-Pulmonary-Complications-In-the-Surgical-and-Critical-Care-SettingsInnovations-in-Endotracheal-Tube-Cuff-Design/21364 
4. Feng TR, Ye Y, Doyle DJ. Critical importance of tracheal tube cuff pressure management. World J Anesth, 2015; 4(2):10-12. http://dx.doi.org/10.5313/wja.v4.i2.10.

5. Ozer AB, Demirel I, Gunduz G, Erhan OL. Effects of user experience and method in the inflation of endotracheal tube pilot balloon on cuff pressure. Nigerian Journal Of Clinical Practice [Internet]. 2013 Apr;16(2):253-7. Available from: http://0-search.ebscohost.com.wam.seals.ac.za/login.aspx? direct=true $\& \mathrm{db}=\mathrm{mdc} \& \mathrm{AN}=23563472 \&$ site=ehost-live $\&$ scope $=$ site

6. American Thoracic Society. Guidelines for the management of adults with hospital-acquired, ventilator-associated, and healthcare-associated pneumonia. American Journal Of Respiratory And Critical Care Medicine [Internet]. 2005 Feb 15;171(4):388-416. Available from: http://0search.ebscohost.com.wam.seals.ac.za/login.aspx?direct=true\&db=cmedm\&AN=15699079\&site=ehost-live\&scope=site 7

7. Sole ML, Xiaogang Su, Talbert S, Penoyer DA, Kalita S, Jimenez E, et al. Evaluation of an intervention to maintain endotracheal tube cuff pressure within therapeutic range. American Journal of Critical Care [Internet]. 2011 Mar;20(2):109-18. Available from: http://0search.ebscohost.com.wam.seals.ac.za/login.aspx?direct=true\&db=ccm\&AN=104827212\&site=ehost-live\&scope=site

8. Registered Nurses Association Ontario. Toolkit: Implementation of Best Practice Guidelines, $2^{\text {nd }}$ Toronto, ON: RNAO; 2012 Sept 1 https://www.google.com/search? $q=8 .+$ Registered+Nurses+Association+Ontario.+Toolkit+\%3A+Implementation+of+Best+Practice+Guidelines\&oq=8.+Registered+Nurses+Association+Onte 8

9. Hamilton VA, Grap MJ. The role of the endotracheal tube cuff in microaspiration. Heart \& Lung: The Journal Of Critical Care [Internet]. 2012 Mar;41(2):167-72. Available from: http://0-search.ebscohost.com.wam.seals.ac.za/login.aspx?direct=true\&db=cmedm\&AN=22209048\&site=ehostlive\&scope=site.

10. Acolet D, Allen E, Houston R, Wilkinson AR, Costeloe K, Elbourne D. Improvement in neonatal intensive care unit care: a cluster randomised controlled trial of active dissemination of information. Archives Of Disease In Childhood Fetal And Neonatal Edition [Internet]. 2011 Nov;96(6):F434-9. Available from: http://0-search.ebscohost.com.wam.seals.ac.za/login.aspx?direct=true\&db=cmedm\&AN=21393310\&site=ehost-live \&scope=site

11. Bhatta K, Greer R. Awareness and monitoring of tracheal tube cuff pressure in a multidisciplinary intensive care unit. Anaesthesia And Intensive Care [Internet]. 2007 Apr;35(2):302-3. Available from: http://0-search.ebscohost.com.wam.seals.ac.za/login.aspx? direct=true \&db=cmedm\&AN=17447298\&site=ehost-live\&scope=site

12. Mohammed A, Mohamed M, Salah M, El-Hosaney WA. Effect of educational program on nurses' knowledge regarding care of adult patients with endotracheal tube; 2016. Available from:

https://www.researchgate.net/publication/331000283_Effect_of_Educational_Program_on_Nurses'_Knowledge_Regarding_Care_of_Adult_Patients_with_E [accessed Aug 28 2019].

13. Jordan .J. Evidence-informed clinical guidelines for nursing care practices related to the safety of the mechanically ventilated patient. [Doctoral thesis] Nelson Mandela Metropolitan University, Port Elizabeth, South Africa; 2011.

14. Jordan P, Van Rooyen D, Venter D. Endotracheal tube cuff pressure management in adult critical care units. Southern African Journal of Critical Care [Internet]. 2012;28(1):13-6. Available from: http://0-search.ebscohost.com.wam.seals.ac.za/login.aspx?direct=true\&db=asn\&AN=82128716\&site=ehostlive\&scope $=$ site

15. Spittle CNS, Beavis SE. Do you measure tracheal cuff pressure? A survey of clinical practice. Brit J Anaes. 2001; 87(2), 344-345.

16. Penitenti R, de M, Vilches J I G, Oliveira JSC, de Mizohata M G G, Correa DI, Alonso TRMB, et al. Cuff pressure control in intensive care unit: training effects. Revista Brasileira De Terapia Intensiva. 2010; 22(2), 192-195. Retrieved from http://0-search.ebscohost.com.wam.seals.ac.za/login.aspx? direct=true \&db=cmedm\&AN=25303762\&site=ehost-live\&scope=site

17. Jam Gatell MR, Santé Roig M, Hernández Vian Ó, Carrillo Santín E, Turégano Duaso C, Fernández Moreno I, Vallés Daunis J. Assessment of a training programme for the prevention of ventilator-associated pneumonia. Nurs Crit Care. 2012 17(6), 285-292. https://0doi.org.wam.seals.ac.za/10.1111/j.1478-5153.2012.00526.x

18. The AGREE Research Trust. Appraisal of Guidelines for ResEarch \& Evaluation Il; 2013. https://www.agreetrust.org/wpcontent/uploads/2013/06/AGREE_II_Users_Manual_and_23-item_Instrument_ENGLISH.pdf

19. Pannucci C J, Wilkins E G. Identifying and avoiding bias in research. Plastic And Reconst Surg. 2010;126(2), 619-625. https://0doi.org.wam.seals.ac.za/10.1097/PRS.0b013e3181de24bc

20. Gheshlaghi RJA. Investigation of effectiveness of in-service education on nurses' knowledge and practice in endotracheal tube cuff care management. [Dissertation] Master's Degree of Critical Care Nursing. Tehran University of Medical Sciences School of Nursing and Midwifery. p. 1-4; 2015.

21. Jun J, Kovner CT, Stimpfel AW. Barriers and facilitators of nurses' use of clinical practice guidelines: An integrative review. International Journal of Nursing Studies [Internet]. 2016 Aug;60:54-68. Available from: http://0-search.ebscohost.com.wam.seals.ac.za/login.aspx? direct=true\&db=asn\&AN=116088393\&site=ehost-live \&scope=site

22. Gilliland L, Perrie H, Scribante J. Endotracheal tube cuff pressures in adult patients undergoing general anaesthesia in two Johannesburg academic hospitals. Southern African Journal of Anaesthesia \& Analgesia [Internet]. 2015 Aug ;21(3):35-84. Available from: http://0-

search.ebscohost.com.wam.seals.ac.za/login.aspx?direct=true\&db=asn\&AN=108954498\&site=ehost-live\&scope=site

23. Labeau SO, Bleiman M, Rello J, Vandijck DM, Claes B, Blot SI. Knowledge and management of endotracheal tube cuffs. International Journal of Nursing Studies [Internet]. 2015 Jan;52(1):498-9. Available from: http://0-search.ebscohost.com.wam.seals.ac.za/login.aspx?

direct=true\&db=ccm\&AN=103860086\&site=ehost-live\&scope=site.

24. Morton PC, Fontaine DK. Critical Care Nursing: a holistic approach, 9th Edition. Philadelphia: Lippincott Williams \& Wilkins; 2009.

Page 12/14 
25. Nseir S, Zerimech F, Fournier C, Lubret R, Ramon P, Durocher A, et al. Continuous control of tracheal cuff pressure and microaspiration of gastric contents in critically ill patients. American Journal of Respiratory \& Critical Care Medicine [Internet]. 2011 Nov;184(9):1041-7. Available from: http://0-

search.ebscohost.com.wam.seals.ac.za/login.aspx?direct=true\&db=ccm\&AN=108213366\&site=ehost-live\&scope=site

26. Thomas S, Kunzmann U. Age Differences in Wisdom-Related Knowledge: Does the Age Relevance of the Task Matter? Journals of Gerontology Series B: Psychological Sciences \& Social Sciences [Internet]. 2014 Nov;69(6):897-905. Available from: http://0-

search.ebscohost.com.wam.seals.ac.za/login.aspx?direct=true\&db=ccm\&AN=103913950\&site=ehost-live\&scope=site

27. Jansson M, Ala-Kokko T, Ylipalosaari P, Syrjälä H, Kyngäs H. Critical care nurses' knowledge of, adherence to and barriers towards evidence-based guidelines for the prevention of ventilator-associated pneumonia - A survey study. Intensive \& Critical Care Nursing [Internet]. 2013 Aug;29(4):216-27. Available from: http://0-search.ebscohost.com.wam.seals.ac.za/login.aspx?direct=true\&db=ccm\&AN=104183699\&site=ehost-live\&scope=site

28. Kostrey Horner D. Mentoring: Positively Influencing Job Satisfaction and Retention of New Hire Nurse Practitioners. Plastic Surgical Nursing [Internet]. 2017 Jan;37(1):7-22. Available from: http://0-search.ebscohost.com.wam.seals.ac.za/login.aspx?direct=true\&db=ccm\&AN=122027206\&site=ehostlive\&scope=site

29. Vergara JY. Implementation of a Mentorship Program to Increase Staff Satisfaction and Retention in Critical Care. Nurse Leader [Internet]. 2017 Jun [cited 2019 Sep 12];15(3):207-12. Available from: http://0-search.ebscohost.com.wam.seals.ac.za/login.aspx? direct=true $\& \mathrm{db}=\mathrm{ccm} \& \mathrm{AN}=123371128 \&$ site $=$ ehost-live $\&$ scope $=$ site

30. SandfordWhat do critical care nurses perceive as barriers to mentorship within the critical care environment? 2013. https://ourarchive.otago.ac.nz/bitstream/handle/10523/3897/SandfordGermaine2013MHealSc.PDF?sequence=1\&isAllowed=y.

31. Sibiya MN, Ngxongo TSP, Beepat SY. The influence of peer mentoring on critical care nursing students' learning outcomes. International Journal Of Workplace Health Management [Internet]. 2018;11(3):130-42. Available from: http://0-search.ebscohost.com.wam.seals.ac.za/login.aspx? direct=true \&db=cmedm\&AN=30166994\&site=ehost-live\&scope=site

32. Perrie H, Schmollgruber S, Bruce JC, Becker PJ. Knowledge of intensive care nurses in selected care areas commonly guided by protocols. Southern African Journal of Critical Care [Internet]. 2014 Aug;30(1):14-8. Available from: http://0-search.ebscohost.com.wam.seals.ac.za/login.aspx? direct=true $\& \mathrm{db}=$ asn $\& A \mathrm{~N}=109010709 \&$ site=ehost-live $\&$ scope $=$ site

33. Gomersall CD. Critical care in the developing world - a challenge for us all. Critical Care (London, England) [Internet]. 2010;14(2):131. Available from: http://0-search.ebscohost.com.wam.seals.ac.za/login.aspx?direct=true\&db=mdc\&AN=20346092\&site=ehost-live\&scope=site

34. Haniffa R, Lubell Y, Cooper BS, Mohanty S, Alam S, Karki A, et al. Impact of a structured ICU training programme in resource-limited settings in Asia. Plos One [Internet]. 2017 Mar 14;12(3):e0173483. Available from: http://0-search.ebscohost.com.wam.seals.ac.za/login.aspx? direct=true \&db=mdc\&AN=28291809\&site=ehost-live\&scope=site

35. Elmabruk R. Enhancing continuous professional development for Libyan in-service EFL teachers: A conceptual framework; 2014. https://www.researchgate.net/publication/327573282_Enhancing_Continuous_Professional_Development_for_Libyan_Inservice_EFL_Teachers_A_conceptual_framework

36. Grol R. Successes and failures in the implementation of evidence-based guidelines for clinical practice. Medical Care [Internet]. 2001 Aug;39(8 Suppl 2):II6-II54. Available from: http://0-search.ebscohost.com.wam.seals.ac.za/login.aspx?direct=true\&db=cmedm\&AN=11583121\&site=ehostlive\&scope=site

37. Harvey G, Kitson A. Translating evidence into healthcare policy and practice: Single versus multi-faceted implementation strategies - is there a simple answer to a complex question? International Journal Of Health Policy And Management [Internet]. 2015 Mar 5;4(3):123-6. Available from: http://0search.ebscohost.com.wam.seals.ac.za/login.aspx?direct=true\&db=mdc\&AN=25774368\&site=ehost-live\&scope=site

38. Fischer F, Lange K, Klose K, Greiner W, Kraemer A. Barriers and Strategies in Guideline Implementation-A Scoping Review. Healthcare (Basel, Switzerland) [Internet]. 2016 Jun 29; 4(3). Available from: http://0-search.ebscohost.com.wam.seals.ac.za/login.aspx? direct $=$ true $\& \mathrm{db}=\mathrm{cmedm} \& \mathrm{AN}=27417624 \&$ site $=$ ehost-live $\&$ scope $=$ site

\section{Figures}
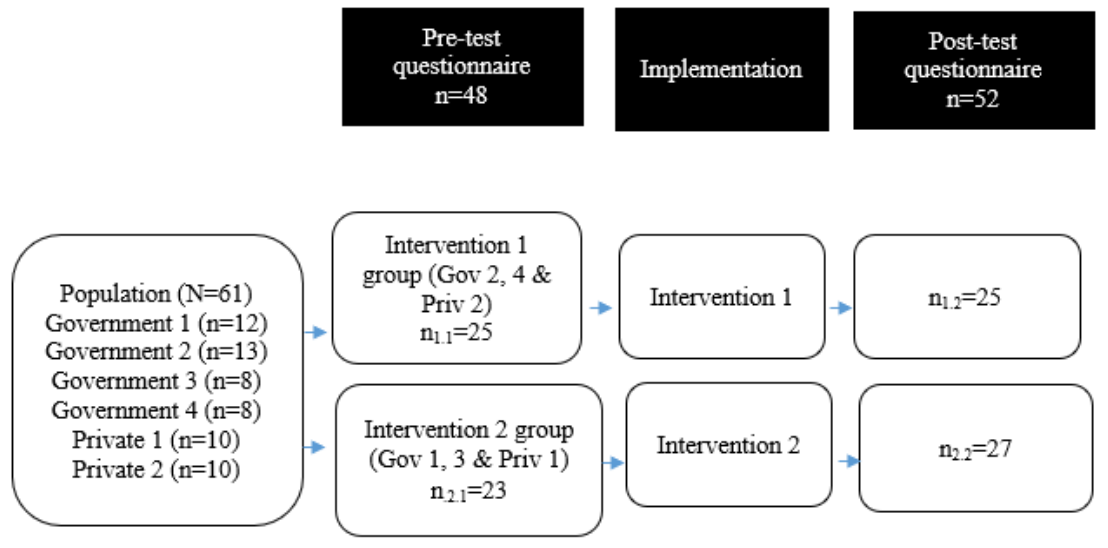

Page $13 / 14$ 
Figure 1

Sampling framework per intervention group

\section{Supplementary Files}

This is a list of supplementary files associated with this preprint. Click to download.

- CONSORT2010Checklist.pdf 